\title{
Application of Multivariate Statistical Techniques for Characterization of Groundwater Quality in the Coastal Aquifer of Nador, Tipaza (Algeria)
}

\author{
Abdelkader BOUDERBALA ${ }^{1}$, Boualem REMINI ${ }^{2}$, \\ Abdelamir SAAED HAMOUDI ${ }^{3}$, and Antonio PULIDO-BOSCH ${ }^{4}$ \\ ${ }^{1}$ Department of Earth Sciences, University of Khemis, Miliana, Algeria \\ e-mail: bouderbala.aek@gmail.com \\ ${ }^{2}$ Department of Water Sciences, University of Blida, Blida, Algeria \\ ${ }^{3}$ Department of Hydraulic, University of Chlef, Chlef, Algeria \\ ${ }^{4}$ Department of Biology and Geology (Hydrogeology), University of Almeria, \\ La Cañada, Spain
}

\begin{abstract}
The study focuses on the characterization of the groundwater salinity on the Nador coastal aquifer (Algeria). The groundwater quality has undergone serious deterioration due to overexploitation. Groundwater samplings were carried out in high and low waters in 2013, in order to study the evolution of groundwater hydrochemistry from the recharge to the coastal area. Different kinds of statistical analysis were made in order to identify the main hydrogeochemical processes occurring in the aquifer and to discriminate between different groups of groundwater. These statistical methods provide a better understanding of the aquifer hydrochemistry, and put in evidence a hydrochemical classification of wells, showing that the area with higher salinity is located close to the coast, in the first two kilometers, where the salinity gradually increases as one approaches the seaside and suggests the groundwater salinization by seawater intrusion.
\end{abstract}

Key words: coastal aquifer, statistical analysis, hydrogeochemical parameters, groundwater quality, seawater intrusion. 


\section{INTRODUCTION}

Groundwater in coastal plains is often the main source of water supply for irrigation, industrial, and domestic purposes, often provoking salinization processes; this is due to the rapid population growth, industrial and agricultural activities in these areas which become the most important factors leading to groundwater exploitation. The notable exploitation of groundwater not only increases the seawater intrusion in coastal regions, but also causes the deterioration of the water quality (Park et al. 2005, Sherif et al. 2006, Mondal et al. 2013, Re et al. 2014). In arid and semi-arid areas, groundwater is often characterized by poor quality, particularly with high salinity (Saxena et al. 2004, Melloul and Collin 2006, Kim et al. 2009, Chekirbane et al. 2013).The problems associated with natural saline groundwater, saltwater intrusion, and upcoming of saltwater in pumping wells are the major concern in many coastal aquifers in the world (Custodio 2002, Lee and Song 2007, Mondal et al. 2008, Giménez-Forcada et al. 2010).

In many coastal Algerian aquifers, groundwater is under constant threat of saline water intrusion. In Algeria, the water demands have revealed significant deficit, whose need is estimated at $7.0 \mathrm{~mm}^{3} /$ day of which only $2.8 \mathrm{~mm}^{3} /$ day is available. Beyond the impact of population growth, water demand has been rising in response to industrial development and increased reliance on irrigated agriculture. The problem of water shortage is prominent in the populated coastal cities (Djabri et al. 2014). Tipaza is one of the coastal cities in Algeria that are facing this problem. It has an agricultural vocation. Orange trees, vineyards and vegetables in greenhouses are the main cultures in the area (Bouderbala 2015). The excessive exploitation of groundwater by farmers during the period 1988-2001 has drastically affected the groundwater reserves and at the same time groundwater gets a high electrical conductivity value, above $9000 \mu \mathrm{S} / \mathrm{cm}$ in 1995. Due to this increase of salinity, several boreholes and wells have been abandoned. At present, water supply for both drinking and irrigation is ensured in the majority part from Boukourdane dam located upstream of the study area (Bouderbala and Remini 2014, Bouderbala et al. 2014).

The objective of this study is to identify the mechanisms of groundwater salinization and to delineate their spatial extension using hydrogeological and hydrogeochemical approaches. Such knowledge will contribute to adapt adequate water management strategies, as well as to prevent quantitative and qualitative alteration of the environmental conditions.

\section{GEOLOGICAL AND HYDROGEOLOGICAL SETTING}

The plain of Wadi Nador belongs to a large coastal morphological unit called the Algiers Sahel, located approximately $75 \mathrm{~km}$ west of Algiers. It is 

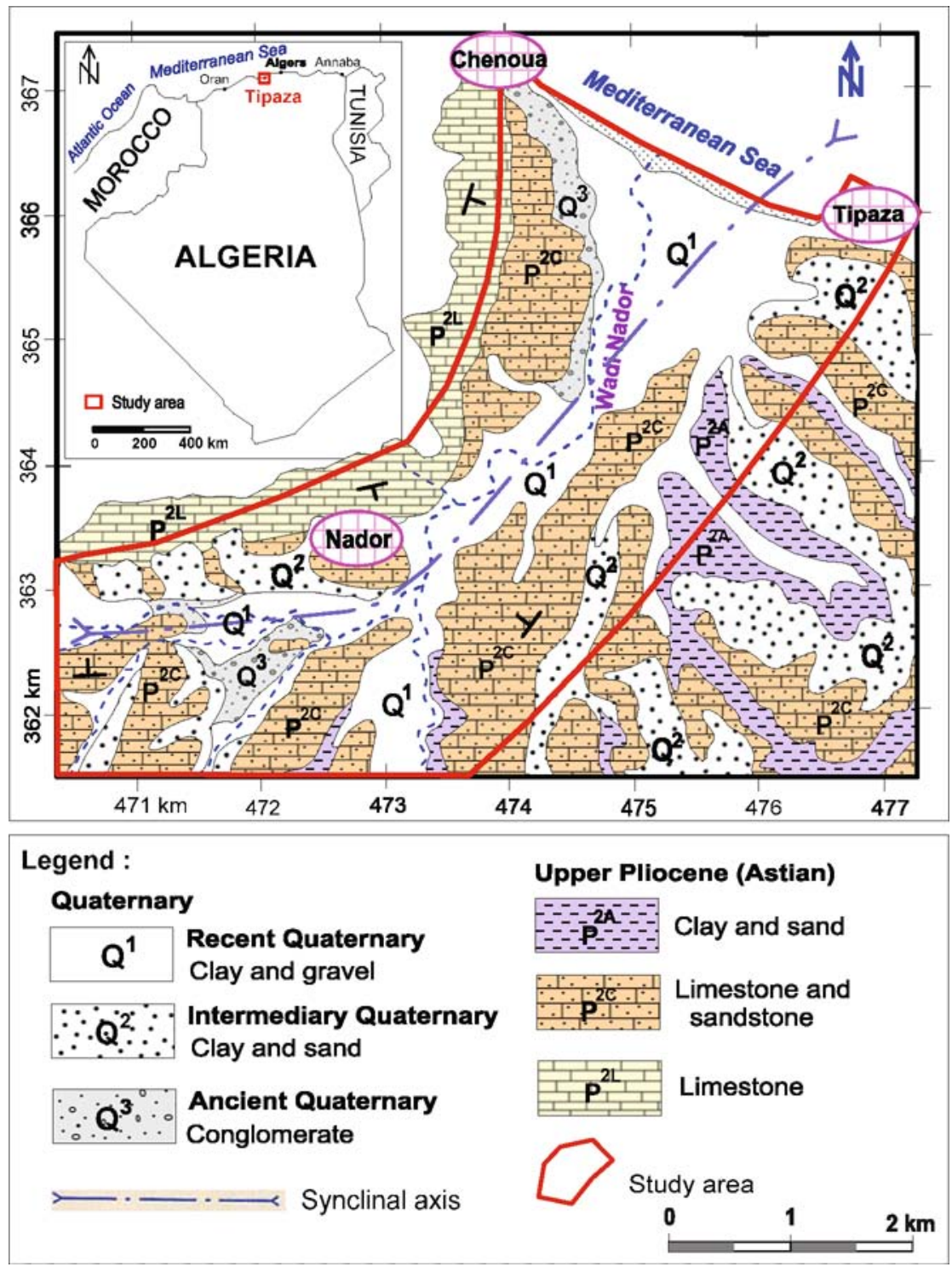

Fig. 1. Geological map of the study area.

limited on the north by the Mediterranean Sea, on the south and east by the slopes of the Sahel, and on the west by the Chenoua Massif (Fig. 1). The plain follows a syncline oriented NE-SW, whose main axis is occupied by the Wadi Nador, which gives its name to the study area. The relief of the Nador plain is characterized by slopes of between 0 and $1 \%$, whilst the 
slopes of the hills and piedmont to both the east (slopes of the Sahel) and west (Chenoua Massif) have gradients of slope between 1 and 10\%.

From a climatological point of view, the area is characterized by a semiarid climate, with average annual rainfall of $540 \mathrm{~mm}$ (period 1988-2012, Boukourdane weather station), and an average annual temperature of $18.0^{\circ} \mathrm{C}$. The annual evapotranspiration, estimated with the Thornthwaite method, is about $424 \mathrm{~mm}$; annual runoff and is estimated to be $70 \mathrm{~mm}$, while infiltration is estimated to be $46 \mathrm{~mm}$ (period 1988-2012).

From the geological point of view, the study area is occupied by Pliocene and Quaternary terrains. The Pliocene is represented by Plaisancian clayey marl, overlying Astian limestone and sandstone. The basement of the Pliocene aquifer is formed by low-permeability clayey marl. Meanwhile, the aquifer is characterized by high permeability, with values of up to $6.8 \times$ $10^{-4} \mathrm{~m} / \mathrm{s}$, a mean saturated thickness of $60 \mathrm{~m}$, and a transmissivity value of about $2.0 \times 10^{-2} \mathrm{~m}^{2} / \mathrm{s}$. The Quaternary terrains are formed by sand, clay, and gravel, reaching a thickness of $30 \mathrm{~m}$ in the centre of the plain. Their permeability is about $10^{-3} \mathrm{~m} / \mathrm{s}$ and the transmissivity is $10^{-2} \mathrm{~m}^{2} / \mathrm{s}$. There are local deposits of clay and sandy clay overlying all these materials. The PlioQuaternary aquifer is partially confined by Quaternary formations (clays, gravels, and sands) in the centre and downstream of the plain.

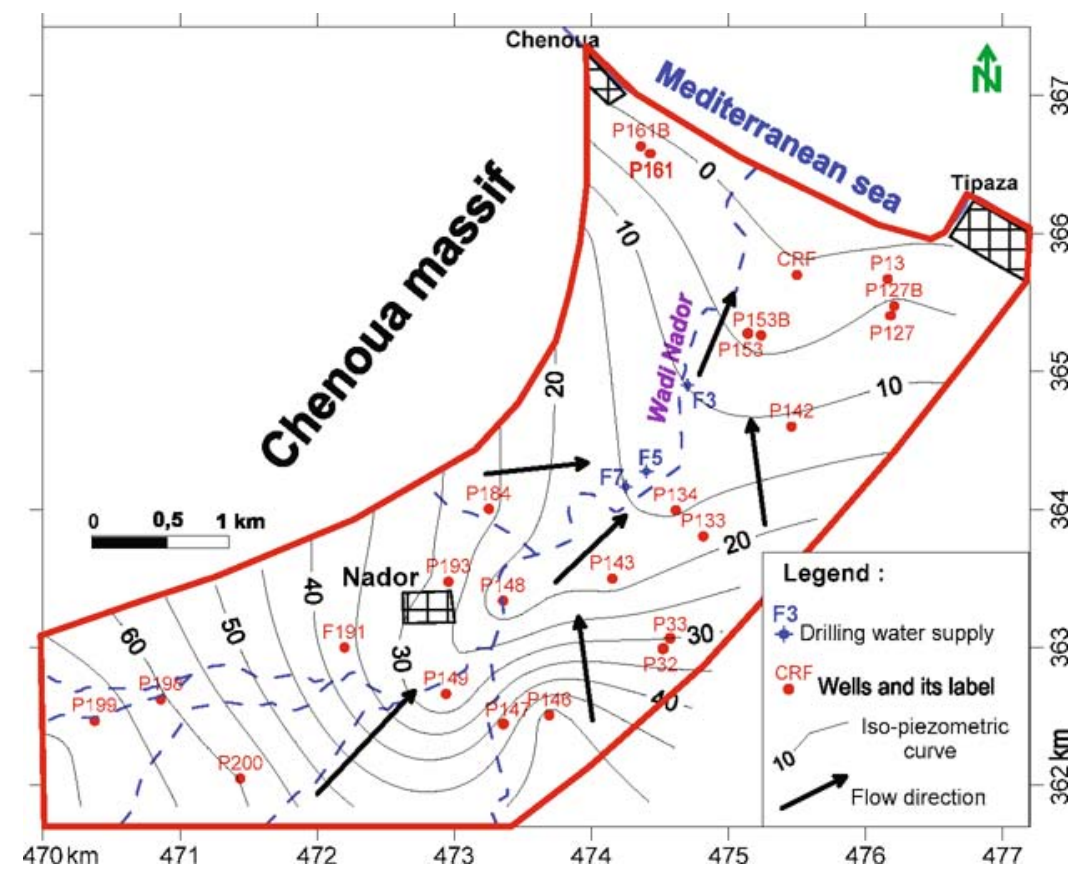

Fig. 2. Piezometric map of Nador aquifer (September 2013). 
The depth of water table is located at only a few metres in downstream sectors, but it is at more than $30 \mathrm{~m}$ in the upstream of plain. Most of the recharge to this Plio-Quaternary aquifer comes from the rainfall infiltration on the permeable outcrops of the plain, and by irrigation return flow. Recharge by the Wadi Nador is much reduced because the banks of the watercourse are clogged with clay. However, the axis of the synclinal nearly coincides with the flow direction of Wadi Nador (Bouderbala and Remini 2014).

The intensive exploitation of the aquifer before 2001 provoked negative values of piezometric water levels around the boreholes situated in the centre of the plain; it favoured the rupture of the hydrodynamic balance between freshwater and seawater, provoking an eventual seawater intrusion in the coastal area.

The piezometric map related to the year 2013 (Fig. 2), after reduction of the pumping rate in the aquifer, shows that groundwater flow lines converge towards the axis of the syncline which constitutes the axis of principal drainage of the Plio-Quaternary aquifer. Then, groundwater flows NE towards the Mediterranean Sea, its natural discharge area.

\section{MATERIAL AND METHODS}

Field samplings have been collected from 24 monitoring wells tapping the aquifer, in April and September 2013. Most of the wells used for sampling are less than $40 \mathrm{~m}$ deep. Samples were collected in cleaned polythene bottles (500 $\mathrm{ml}$ capacity) and were properly labelled, indicating the well number, date, and time of collection. All of the samples were analyzed using standard procedures (APHA 1995). Total dissolved solids (TDS), electrical conductivity (EC), and $\mathrm{pH}$ were analyzed in situ using a multi-parameter measurement WTW 3410 IDS. Major ions chlorides, bicarbonates, were analyzed using volumetric methods. Calcium, magnesium, sodium, and potassium were analyzed using atomic adsorption spectrometry. Nitrates were measured by a colorimetric method. Sulphates were estimated by the UV-visible spectrophotometer. The precision and accuracy of all analysis were within $\pm 5 \%$.

In order to better understand the hydrogeochemical processes that take place in coastal aquifer, seawater fraction, ionic deltas, and saturation indices were used, which facilitate interpretation of the evolutionary trends and hydrogeochemical processes occurring in the groundwater of this aquifer.

The seawater fraction in the groundwater is often estimated using chloride concentration, since this ion has been considered as a conservative tracer, and it is not affected by ion exchange (Custodio 1987). It can be estimated using the following mixing equation (Appelo and Postma 2005): 


$$
f_{\text {sea }}=\left(C_{\mathrm{Cl}, \text { sample }}-C_{\mathrm{Cl}, \text { fresh }}\right) \times \frac{100}{\left(C_{\mathrm{Cl}, \text { sea }}-C_{\mathrm{Cl}, \text { fresh }}\right)},
$$

where $C_{\mathrm{Cl} \text {,sample }}$ is the $\mathrm{Cl}^{-}$concentration of the sample, $C_{\mathrm{Cl} \text {,sea }}$ is the $\mathrm{Cl}^{-}$ concentration of the Mediterranean Sea, and $C_{\mathrm{Cl} \text {,fresh }}$ represents the $\mathrm{Cl}^{-}$ concentration of the freshwater.

Calculation of ionic deviations $(\Delta)$ corresponds to a comparison of measured concentration of each constituent to its theoretical concentration of a known theoretical freshwater-seawater mixture (Kouzana et al. 2009, Mondal et al. 2013). Once calculated, the seawater fraction is used to calculate the theoretical concentration of each ion $i$ resulting from the conservative mixing of seawater and the freshwater:

$$
C_{i, \text { mix }}=f_{\text {sea }} C_{i, \text { sea }}+\left(1-f_{\text {sea }}\right) C_{i, \text { fresh }},
$$

where $C_{i, \text { sea }}$ and $C_{i, \text { fresh }}$ are the concentration of the ion $i$ of, respectively, seawater and freshwater. For each ion $i$, the difference between the concentration of the conservative mixing $C_{i \text {,mix }}$ and the measured one $C_{i \text {,sample }}$ simply represents the ionic deltas $(\Delta)$ (Fidelibus 2003) resulting from any chemical reaction occurring with mixing:

$$
\Delta C_{i}=C_{i, \text { sample }}-C_{i, \text { mix }} .
$$

The state of mineral saturation that reacts in the system during the period of low groundwater in 2013 was calculated from the analytical data sampling. The mineral saturation indices (SI) indicate the degree of saturation in a particular mineral phase compared to the aqueous solution with which it is in contact. Based on this SI value, the trend of precipitation or dilution of the mineral phases can be deduced. The simulation was performed using the thermodynamic software PHREEQC. The calculation of the saturation index was performed by the formula $\mathrm{SI}=[\log (Q)] /[\log (K s p)]$.

In order to identify geochemical processes that contribute to the groundwater salinization in the Nador aquifer, the ionic ratios, Cumulative Probability Curves (CPC) and Cluster Analysis are used to assess the salinity in this aquifer. Different ionic ratios were calculated to support the discrimination of samples, and to try and determine the processes acting in the water. $\mathrm{Ca}^{2+} / \mathrm{Na}^{+}, \mathrm{Ca}^{2+} / \mathrm{Mg}^{2+}, \mathrm{HCO}_{3}{ }^{-} / \mathrm{Cl}^{-}$, and $\mathrm{SO}_{4}{ }^{2-} / \mathrm{Cl}^{-}$(in meq/L) were used to determine the origin of groundwater salinity (Pulido-Leboeuf et al. 2003, Pulido-Leboeuf 2004, Singh et al. 2005, Giménez-Forcada et al. 2010, Mondal et al. 2010, Daniele et al. 2011, Gurunadha Rao et al. 2013).

In order to determine the anomalous population whose chemistry was affected locally by salinization, the CPC of hydrochemical parameters were drawn and interpreted (Park et al. 2005, Mondal and Sing 2011). In particular, the density distributions of $\mathrm{Na}^{+}, \mathrm{Mg}^{2+}, \mathrm{Cl}^{-}$, and $\mathrm{SO}_{4}{ }^{2-}$ concentrations 
were carefully examined in this study in order to group the collected samples on the basis of seawater mixing (Lee and Song 2007, Mondal et al. 2011). If a chosen water quality parameter is affected by a single process, the frequency distribution of its concentration forms a unimodal, normal or log-normal distribution. If so, the cumulative probability plots form a linear distribution in a probability diagram. On the other hand, if the plots of a water quality parameter do not form a linear distribution, the parameter can be considered to be affected by more than one population (process). For such a case, each population can be differentiated by the intersection points of two neighboring linear populations (Park et al. 2005). Multivariate statistical techniques are widely used to identify and evaluate groundwater quality in environmental studies. It can be used to simplify, organize, and classify groundwater data in order to bring about useful meanings (Sarwade et al. 2007, Arslan 2013, Charfi et al. 2013, Matiatos et al. 2014). It was performed through Cluster Analysis (CA). The samples were statistically analyzed by using the software Statgraphics plus 5.1. A number of studies used this technique to successfully classify water samples (Moral Callejón et al. 1984, Liu et al. 2003, Gupta et al. 2005, Yidana 2010, Belkhiri et al. 2011, Zhang et al. 2011).

\section{RESULTS AND DISCUSSION}

\subsection{Geochemical composition of groundwater}

The statistical results of analyzed groundwater samples parameters of the study area are summarized in Table 1 . The EC values have a wide range, from 1360 to $4620 \mu \mathrm{S} / \mathrm{cm}$ (an averages of 2094 and $2295 \mu \mathrm{S} / \mathrm{cm}$ for the high and low water periods, respectively), and TDS values range between 890 and $3079 \mathrm{mg} / \mathrm{L}$ (an averages of 1463 and $1536 \mathrm{mg} / \mathrm{L}$ for the high and low water periods, respectively). More than $70 \%$ of the samples exceeded the guideline values of drinking water quality (WHO 2011) for EC and TDS. The $\mathrm{pH}$ values ranged from 7.0 to 7.95 , indicating a slightly alkaline nature.

In general, the cationic concentration indicates that $37.5 \%$ of the groundwater samples have $\mathrm{Na}^{+}>\mathrm{Mg}^{2+}>\mathrm{Ca}^{2+}>\mathrm{K}^{+}$for the coastal samples and $62.5 \%$ have $\mathrm{Ca}^{2+}>\mathrm{Na}^{+}>\mathrm{Mg}^{2+}>\mathrm{K}^{+}$for the samples in the recharge area, while for the anionic concentration, $46 \%$ of the groundwater samples have $\mathrm{Cl}^{-}>\mathrm{SO}_{4}{ }^{2-}>\mathrm{HCO}_{3}{ }^{-}$for the coastal samples, and $46 \%$ of samples in the recharge area have $\mathrm{HCO}_{3}{ }^{-}>\mathrm{Cl}^{-}>\mathrm{SO}_{4}{ }^{2-} .8 \%$ of the samples belong to $\mathrm{SO}_{4}{ }^{2-}>\mathrm{Cl}^{-}>\mathrm{HCO}_{3}^{-}$. The nitrate concentrations in groundwater samples vary from 4 to $75 \mathrm{mg} / \mathrm{L}$ and from 4 to $79 \mathrm{mg} / \mathrm{L}$ for high and low water periods, respectively; there are about $20 \%$ of samples that have a concentration greater than $50 \mathrm{mg} / \mathrm{L}$. The lower and moderate values of nitrate are found in the southern part (recharge area); this is explained by high permeability of the unsaturated zone. 
Table 1

Statistical parameters of groundwater samples (period 2013)

\begin{tabular}{|c|c|c|c|c|c|c|c|c|c|}
\hline \multirow{2}{*}{$\begin{array}{l}\text { Para- } \\
\text { meters }\end{array}$} & \multirow{2}{*}{$\begin{array}{c}\text { Norm } \\
\text { (WHO } \\
2011 \text { ) }\end{array}$} & \multicolumn{4}{|c|}{ High water period } & \multicolumn{4}{|c|}{ Low water period } \\
\hline & & Max. & Min. & Mean & $\begin{array}{c}\%> \\
\text { WHO }\end{array}$ & Max. & Min. & Mean & $\begin{array}{c}\%> \\
\text { WHO }\end{array}$ \\
\hline TDS & 1000 & 2885 & 890 & 1463.5 & 70.8 & 3079 & 955 & 1536.4 & 83.3 \\
\hline $\mathrm{EC}$ & 1500 & 4400 & 1360 & 2189.5 & 70.8 & 4620 & 1430 & 2294.5 & 83.3 \\
\hline $\mathrm{pH}$ & $6.5-8.5$ & 7.9 & 7.0 & 7.4 & 0 & 7.7 & 7.1 & 7.4 & 0 \\
\hline $\mathrm{NO}_{3}^{-}$ & 50 & 75 & 4 & 34.6 & 20.8 & 79 & 4 & 36.0 & 20.8 \\
\hline $\mathrm{HCO}_{3}^{-}$ & 300 & 469 & 280 & 382.5 & 91.6 & 492 & 295 & 399.6 & 91.6 \\
\hline $\mathrm{SO}_{4}^{2-}$ & 250 & 1080 & 102 & 434.6 & 54.2 & 1135 & 107 & 455.9 & 54.2 \\
\hline $\mathrm{Cl}^{-}$ & 250 & 2001 & 156 & 634.4 & 50 & 2100 & 165 & 665.3 & 54.2 \\
\hline $\mathrm{Na}^{+}$ & 200 & 1288 & 85 & 381.8 & 37.5 & 1355 & 89 & 394.4 & 37.5 \\
\hline $\mathrm{Mg}^{2+}$ & 50 & 284 & 29 & 116.2 & 45.8 & 295 & 30 & 119.5 & 50 \\
\hline $\mathrm{Ca}^{2+}$ & 100 & 194 & 128 & 157.9 & 100 & 195 & 149 & 166.5 & 100 \\
\hline $\mathrm{K}^{+}$ & 12 & 7.82 & 0 & 2.9 & 0 & 11.73 & 0 & 7.5 & 0 \\
\hline
\end{tabular}

Note: TDS and ions are expressed in $\mathrm{mg} / \mathrm{L}, \mathrm{EC}$ is expressed in $\mu \mathrm{S} / \mathrm{cm}$.

The map of groundwater EC of low period 2013 shows how the salinity change through the aquifer, with values ranging from 1430 to $4620 \mu \mathrm{S} / \mathrm{cm}$ (Fig. 3). The highest EC was measured in the coastal area, where the water abstracted is too saline for drinking purposes.

With respect to the quality of groundwater, three categories can be considered: (i) $<1500 \mu \mathrm{S} / \mathrm{cm}$ for freshwater, (ii) 1501 to $3000 \mu \mathrm{S} / \mathrm{cm}$ for brackish water, and (iii) $>3000 \mu \mathrm{S} / \mathrm{cm}$ for saline water in coastal aquifers (Saxena et al. 2003, Mondal et al. 2008, Khairy and Janardhana 2013) which gives: 21 and $25 \%$ of the samples found in saline water, 50 and $54 \%$ of brackish water, and the remaining 29 and $21 \%$ of samples are freshwater, for high and low water periods, respectively.

However, $79.2 \%$ and $37.5 \%$ of samples exceeded the guideline values for chloride $\left(\mathrm{Cl}^{-}, 250 \mathrm{mg} / \mathrm{L}\right)$ and sodium $\left(\mathrm{Na}^{+}, 200 \mathrm{mg} / \mathrm{L}\right)$, respectively. So the totality of the samples exceeded the guideline values for calcium $\left(\mathrm{Ca}^{2+}\right.$, $100 \mathrm{mg} / \mathrm{L}$ ).

The Piper diagram was created for Nador plain, using the hydrochemical analysis of September 2013. It shows that a number of wells are found on the theoretical mixing line indicating the mixing process between freshwater and saltwater (Fig. 4). 


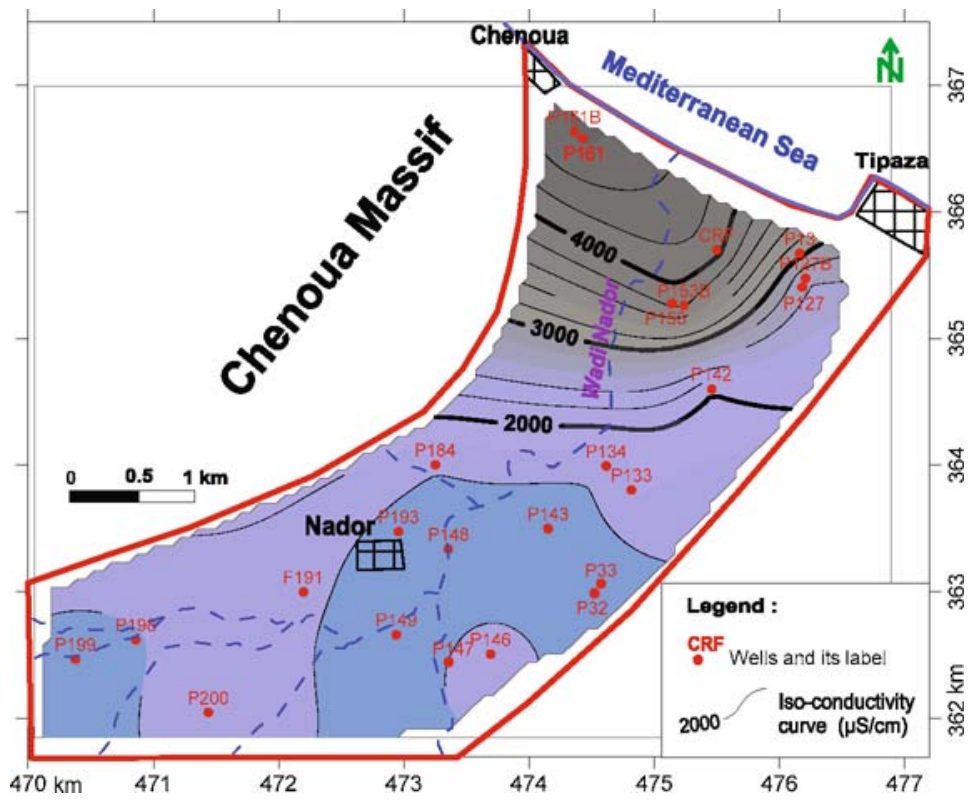

Fig. 3. Map of groundwater EC (September 2013).

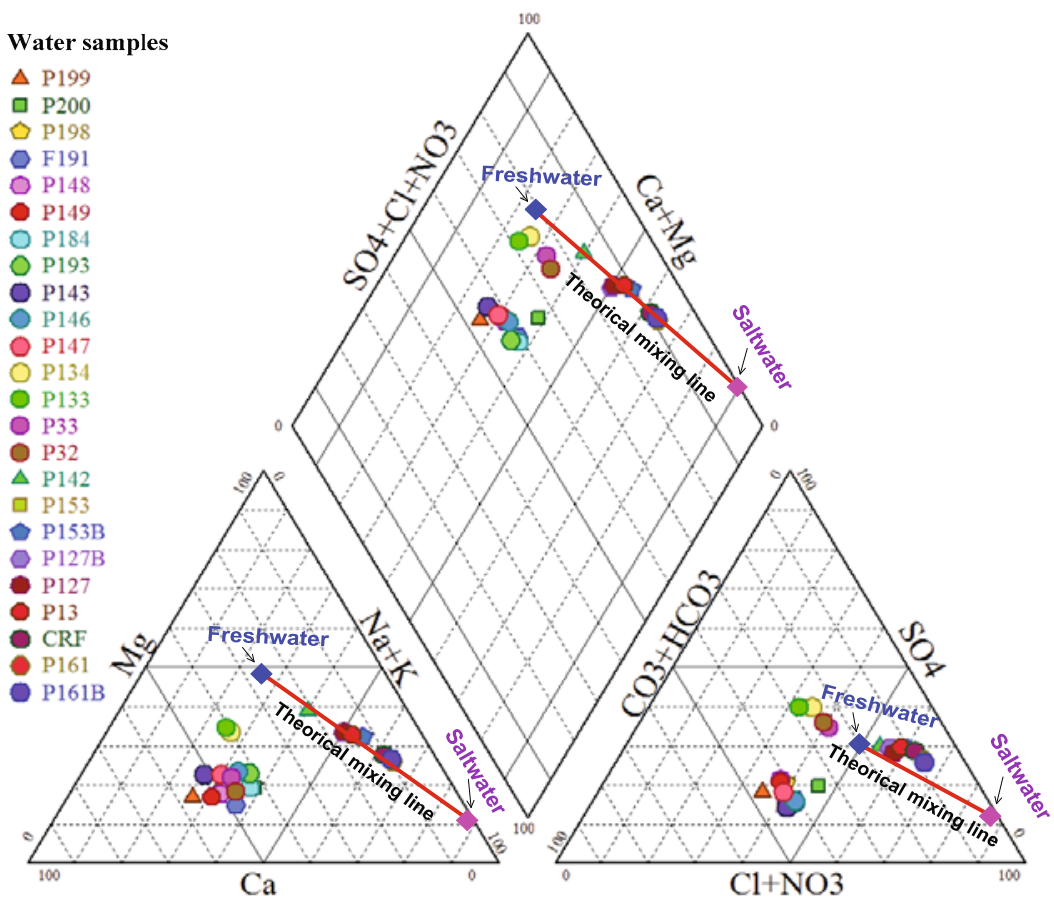

Fig. 4. Piper diagram for groundwater samples (September 2013). 
The diagram illustrates the predominance of the $\mathrm{Ca}-\mathrm{HCO}_{3}$ water type ( $45.83 \%$ of the samples) in the recharge zone. However, in the coastal zone, the water type is $\mathrm{Na}-\mathrm{Cl}(37.5 \%)$ and in the centre of the plain $(16.67 \%)$ the water types are $\mathrm{Mg}-\mathrm{SO}_{4}$ and $\mathrm{Ca}-\mathrm{Cl}$. They are detailed in the Table 2 .

Table 2

Ionic deltas and SI of groundwater samples (September 2013)

\begin{tabular}{|c|c|c|c|c|c|c|c|c|c|}
\hline \multirow{2}{*}{$\begin{array}{c}\text { No. } \\
\text { of wells }\end{array}$} & \multicolumn{4}{|c|}{ Ionic delta } & \multicolumn{4}{|c|}{ SI } & \multirow{2}{*}{ Water type } \\
\hline & $\Delta \mathrm{Na}^{+}$ & $\Delta \mathrm{Ca}^{2+}$ & $\Delta \mathrm{Mg}^{2+}$ & $\Delta \mathrm{SO}_{4}^{2-}$ & Calcite & Dolom. & Gyps. & Halite & \\
\hline P199 & 0.19 & -5.79 & 3.29 & 0.40 & 0.53 & 0.67 & -1.34 & -6.45 & $\mathrm{HCO}_{3}-\mathrm{Cl}-\mathrm{Ca}-\mathrm{Na}$ \\
\hline P200 & 0.82 & -4.85 & 2.67 & 0.87 & 0.62 & 1.02 & -1.29 & -6.04 & $\mathrm{HCO}_{3}-\mathrm{Cl}-\mathrm{Ca}-\mathrm{Na}$ \\
\hline P198 & 0.53 & -5.13 & 3.70 & 1.02 & 0.34 & 0.38 & -1.23 & -6.18 & $\mathrm{HCO}_{3}-\mathrm{Cl}-\mathrm{Ca}-\mathrm{Na}$ \\
\hline F191 & 0.38 & -5.68 & 3.82 & 0.23 & 0.65 & 0.96 & -1.32 & -6.05 & $\mathrm{HCO}_{3}-\mathrm{Cl}-\mathrm{Ca}-\mathrm{Na}$ \\
\hline P148 & 0.64 & -5.65 & 2.58 & 0.79 & 0.44 & 0.56 & -1.30 & -6.32 & $\mathrm{HCO}_{3}-\mathrm{Cl}-\mathrm{Ca}-\mathrm{Na}$ \\
\hline P149 & 0.65 & -5.72 & 2.98 & 0.66 & 0.56 & 0.75 & -1.30 & -6.35 & $\mathrm{HCO}_{3}-\mathrm{Cl}-\mathrm{Ca}-\mathrm{Na}$ \\
\hline P184 & 1.09 & -4.68 & 3.23 & 0.30 & 0.55 & 0.89 & -1.35 & -6.05 & $\mathrm{HCO}_{3}-\mathrm{Cl}-\mathrm{Ca}-\mathrm{Na}$ \\
\hline P193 & 0.69 & -4.24 & 2.44 & 0.10 & 0.80 & 1.47 & -1.43 & -6.11 & $\mathrm{HCO}_{3}-\mathrm{Cl}-\mathrm{Ca}-\mathrm{Na}$ \\
\hline P143 & 0.11 & -4.50 & 3.72 & 0.02 & 0.65 & 1.08 & -1.40 & -6.35 & $\mathrm{HCO}_{3}-\mathrm{Cl}-\mathrm{Ca}-\mathrm{Na}$ \\
\hline P146 & -0.19 & -4.41 & 2.38 & 0.24 & 0.68 & 1.21 & -1.40 & -6.17 & $\mathrm{HCO}_{3}-\mathrm{Cl}-\mathrm{Ca}-\mathrm{Na}$ \\
\hline P147 & 0.23 & -4.67 & 2.72 & 0.51 & 0.68 & 1.15 & -1.35 & -6.33 & $\mathrm{HCO}_{3}-\mathrm{Cl}-\mathrm{Ca}-\mathrm{Na}$ \\
\hline P134 & -0.72 & -0.38 & 4.64 & 7.09 & 0.57 & 1.18 & -0.85 & -6.03 & $\mathrm{SO}_{4}-\mathrm{Cl}-\mathrm{Ca}-\mathrm{Mg}$ \\
\hline P133 & -0.01 & -0.55 & 4.13 & 6.15 & 0.55 & 1.16 & -0.91 & -6.15 & $\mathrm{SO}_{4}-\mathrm{Cl}-\mathrm{Ca}-\mathrm{Mg}$ \\
\hline P33 & -0.98 & -4.42 & 3.39 & 4.42 & 0.36 & 0.52 & -0.97 & -6.04 & $\mathrm{Cl}-\mathrm{SO}_{4}-\mathrm{Ca}-\mathrm{Na}$ \\
\hline P32 & -0.11 & -5.11 & 3.31 & 4.42 & 0.55 & 0.82 & -0.97 & -6.07 & $\mathrm{Cl}-\mathrm{SO}_{4}-\mathrm{Ca}-\mathrm{Na}$ \\
\hline P142 & -2.50 & 5.74 & 2.63 & 6.93 & 0.12 & 0.63 & -0.98 & -5.31 & $\mathrm{Cl}-\mathrm{SO}_{4}-\mathrm{Na}-\mathrm{Mg}$ \\
\hline P153 & -2.18 & 11.76 & 2.88 & 13.55 & 0.25 & 1.03 & -0.82 & -4.58 & $\mathrm{Cl}-\mathrm{SO}_{4}-\mathrm{Na}-\mathrm{Mg}$ \\
\hline P153B & -1.81 & 12.22 & 3.01 & 13.72 & 0.36 & 1.25 & -0.82 & -4.59 & $\mathrm{Cl}-\mathrm{SO}_{4}-\mathrm{Na}-\mathrm{Mg}$ \\
\hline P127B & -2.20 & 5.86 & 1.95 & 8.97 & 0.42 & 1.28 & -0.95 & -4.98 & $\mathrm{Cl}-\mathrm{SO}_{4}-\mathrm{Na}-\mathrm{Mg}$ \\
\hline P127 & -3.85 & 6.07 & 1.84 & 8.85 & 0.52 & 1.48 & -0.95 & -4.95 & $\mathrm{Cl}-\mathrm{SO}_{4}-\mathrm{Na}-\mathrm{Mg}$ \\
\hline P13 & -2.19 & 8.36 & 2.61 & 11.13 & 0.52 & 1.51 & -0.87 & -4.79 & $\mathrm{Cl}-\mathrm{SO}_{4}-\mathrm{Na}-\mathrm{Mg}$ \\
\hline CRF & -2.76 & 8.50 & 1.28 & 14.43 & 0.56 & 1.66 & -0.86 & -4.48 & $\mathrm{Cl}-\mathrm{SO}_{4}-\mathrm{Na}-\mathrm{Mg}$ \\
\hline P161 & 1.15 & 12.41 & 2.28 & 14.60 & 0.65 & 1.86 & -0.83 & -4.27 & $\mathrm{Cl}-\mathrm{SO}_{4}-\mathrm{Na}-\mathrm{Mg}$ \\
\hline P161B & 0.68 & 12.83 & 2.09 & 14.41 & 0.73 & 2.04 & -0.84 & -4.27 & $\mathrm{Cl}-\mathrm{SO}_{4}-\mathrm{Na}-\mathrm{Mg}$ \\
\hline Sea Wat & - & - & - & - & 0.61 & 1.68 & -0.50 & -2.47 & \\
\hline
\end{tabular}

\subsection{Mixing of groundwater}

In coastal aquifers, the mixing between freshwater and saltwater causes significant environmental and economic constraints. Therefore, understanding the extent of mixing of these two types of waters is important in coastal water management, since the presence of even a small fraction of saltwater would make a freshwater system unfit for drinking (Abarca and Clement 2009). The mixing of seawater with the fresh groundwater in the aquifer was calculated using the mass balance equation. In addition, the calculation of 


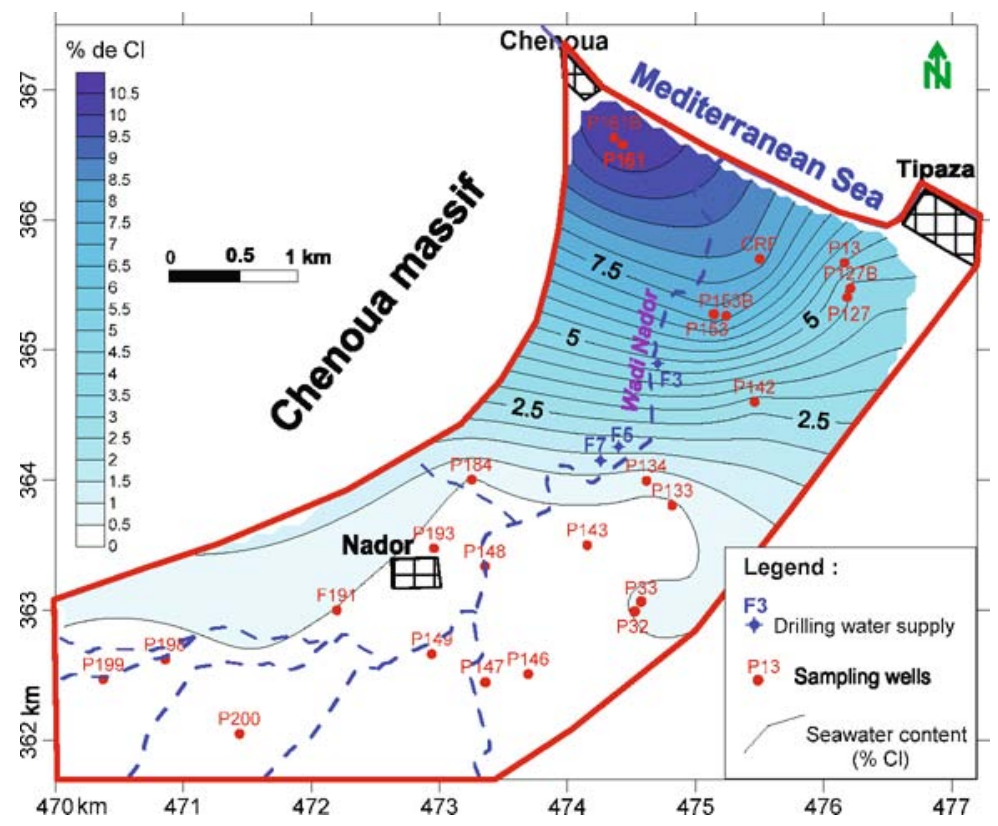

Fig. 5. Spatial distribution of seawater percentage map (September 2013).

these ionic deltas is important for determining and quantifying the hydrogeochemical processes and potential chemical reactions that take place in the aquifer (Pulido-Leboeuf 2004). Hence, when $\Delta C_{i}$ is positive, groundwater is getting enriched in ion $i$, whereas a negative value of $\Delta C_{i}$ indicates a depletion of ion $i$ compared to the theoretical mixing (Anderson et al. 2005).

In this study, the resulting seawater fractions in all observation wells using Eq. 1 are shown in Fig. 5. In the Plio-Quaternary coastal area, the mixing rate of seawater intrusion for observation wells is $10 \%$, confirming the process of seawater intrusion into freshwater aquifer.

We note that the variation value of seawater mixing rate between observation wells is clearly related to their distance from the sea. For example, P161 and P161B, located near to Mediterranean Sea, are the most contaminated wells in the area; their seawater percentage values exceed $10.5 \%$, while upstream of the plain, the mixing rate of seawater intrusion contents values $(<1 \%)$ are due to the infiltration of meteoric water and dilution of groundwater (recharge area).

The ionic deltas of the major elements $\left(\Delta \mathrm{Na}^{+}, \Delta \mathrm{Mg}^{2+}, \Delta \mathrm{Ca}^{2+}\right.$, and $\left.\Delta \mathrm{SO}_{4}{ }^{2}\right)$ versus chloride are plotted to show the relationships between these elements (Fig. 6). Generally, the majority of samples are depleted in $\mathrm{Na}^{+}$and enriched in $\mathrm{Ca}^{2+}, \mathrm{Mg}^{2+}$, and $\mathrm{SO}_{4}{ }^{2-}$. 


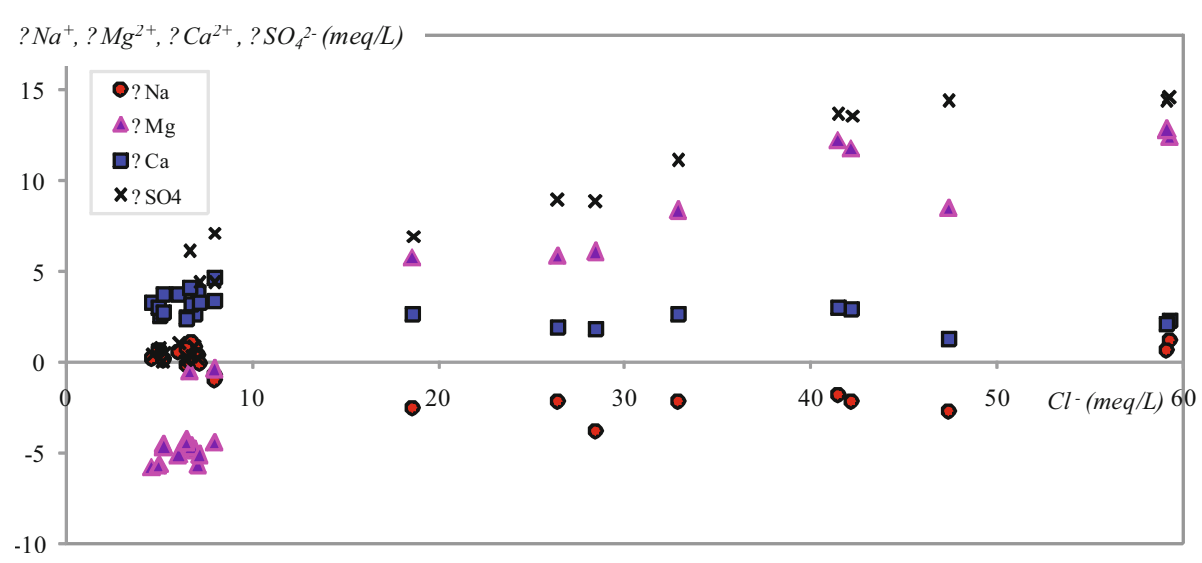

Fig. 6. Relationships of $\Delta \mathrm{Na}^{+}, \Delta \mathrm{Ca}^{2+}, \Delta \mathrm{Mg}^{2+}$, and $\mathrm{SO}_{4}{ }^{2-}$ versus $\mathrm{Cl}^{-}$.

The loss of $\mathrm{Na}^{+}$and gain of $\mathrm{Ca}^{2+}$ and $\mathrm{Mg}^{2+}$ suggests a reverse cation exchange, usually observed in similar situations when the seawater is replacing freshwater (Cardona et al. 2004, Appelo and Postma 2005). A highly linear relationship can be identified between $\mathrm{Cl}^{-}$and $\mathrm{Na}^{+}(r=0.99)$, and their groundwater samples are closely aligned on the theoretical mixing line between freshwater and seawater, indicating that salinity in groundwater is derived from a marine source; the difference in salinity for different samples is due to the variation of the seawater contribution. The ionic deltas of $\Delta \mathrm{Mg}^{2+}$ and $\Delta \mathrm{SO}_{4}{ }^{2-}$ become more positive with the increase of the chloride ion and considerably more positive in the coastal area, when values of $\mathrm{Cl}^{-}$exceed $10 \mathrm{meq} / \mathrm{L}$.

The high values of $\Delta \mathrm{SO}_{4}{ }^{2-}$ are probably due to the excessive use of fertilizers (ammonium sulphate), the irrigation by treated wastewater, the evaporation and the mixing between freshwater and seawater. However, the high values of $\Delta \mathrm{Mg}^{2+}$ are probably due to the mixing between freshwater and seawater.

Saturation index is a measure of the thermodynamic state of a solution relative to equilibrium with specified solid-phase minerals. It is postulated that mineral phases that are undersaturated will tend to dissolve and mineral phases that are oversaturated will precipitate these mineral phases out of solution. Equilibrium is taken to be between $\mathrm{SI}=-0.1$ and $\mathrm{SI}=0.1$.

Saturation indices (SI) for 24 groundwater samples were calculated using software PHREEQC. Results of saturation indices of various different minerals are shown in Table 2. It was found to be undersaturated $(\mathrm{SI} \leq-0.1)$ with respect to gypsum and halite, and oversaturated $(\mathrm{SI} \geq 0.1)$ with respect to calcite and dolomite. 
In the parts of the aquifer which were undersaturated with respect to calcite or dolomite, groundwater flow is capable of dissolving the aquifer rock, thereby increasing both its porosity and permeability (case of recharge area). Whereas in other parts, where the SI is positive, mineral precipitation will have the opposite effect on the aquifer properties (case of coastal area), confirming that the $\mathrm{Ca}^{2+}$ and $\mathrm{Mg}^{2+}$ enrichment is due to cation exchange dependent on the residence time. Another explanation for the increase in the SI of dolomite in coastal wells is probably the mixing phenomenon between freshwater and seawater.

The gypsum and halite saturation indices show undersaturation. Indeed, this dissolution is confirmed by the negative saturation indices of groundwater with respect to gypsum and halite. These salts are then leached, under rainfall, towards the groundwater (Li et al. 2014).

\subsection{Assessment of salinization}

\subsubsection{Ionic ratios}

$\mathrm{Ca}^{2+} / \mathrm{Na}^{+}$ratio can reflect the degree of seawater mixture. Higher $\mathrm{Na}^{+}$can be due to the dissolution of halites, and also to the seawater intrusion in coastal aquifers. However, the origin of calcium maybe due to the dissolution of precipitates of $\mathrm{CaCO}_{3}$ and $\mathrm{CaMg}\left(\mathrm{CO}_{3}\right)_{2}$ during the recharge of aquifer (Lakshmanan et al. 2003). The $\mathrm{Ca}^{2+} / \mathrm{Mg}^{2+}$ ratios of freshwater range from 0.5 to 5 in sedimentary rocks and from 0.25 to 0.5 for seawater intrusion (Custodio 1987, El Moujabber et al. 2006). Figure 7a illustrates the relationship between $\mathrm{Ca}^{2+} / \mathrm{Na}^{+}$and $\mathrm{Ca}^{2+} / \mathrm{Mg}^{2+}$ ratios versus $\mathrm{Cl}^{-}$(in meq/L). When $\mathrm{Ca}^{2+} / \mathrm{Na}^{+}$ ratios are $>1$, the $\mathrm{Cl}^{-}$is $<10 \mathrm{meq} / 1$, indicating an enrichment of $\mathrm{Ca}^{2+}$ relative to $\mathrm{Na}^{+}$, due to the rock-water exchange. However, for the coastal wells, the $\mathrm{Ca}^{2+} / \mathrm{Na}^{+}$ratios tend to 0 , indicating an enrichment of $\mathrm{Na}^{+}$relative to $\mathrm{Ca}^{2+}$, which is probably due to the influence of seawater in this part of aquifer. The $\mathrm{Ca}^{2+} / \mathrm{Mg}^{2+}$ ratios show the same evolution as that of $\mathrm{Ca}^{2+} / \mathrm{Na}^{+}$; indicating an enrichment of $\mathrm{Mg}^{2+}$ relative to $\mathrm{Ca}^{2+}$ for the coastal samples. Generally, the sources of magnesium are dissolution of dolomites and silicate weathering. However, in this coastal area, higher $\mathrm{Mg}^{2+}$ contents maybe due to saline intrusion, while in the recharge area (upstream area) the low $\mathrm{Ca}^{2+} / \mathrm{Mg}^{2+}$ ratios could be explained by the rock-water exchange interaction like limestone and clay minerals among the sedimentary rocks of this coastal region. This is due to the existence of direct cation exchanges reactions, which withdraw $\mathrm{Ca}^{2+}$ and give to $\mathrm{Na}^{+}$and $\mathrm{Mg}^{2+}$ (Pulido-Leboeuf et al. 2003, Kouzana et al. 2009, Kolsi et al. 2013).

The effect of salinization could be classified also using the $\mathrm{HCO}_{3}{ }^{-} / \mathrm{Cl}^{-}$ ratio, which includes values $>0.5$ for unaffected, $0.2-0.5$ for slightly and 

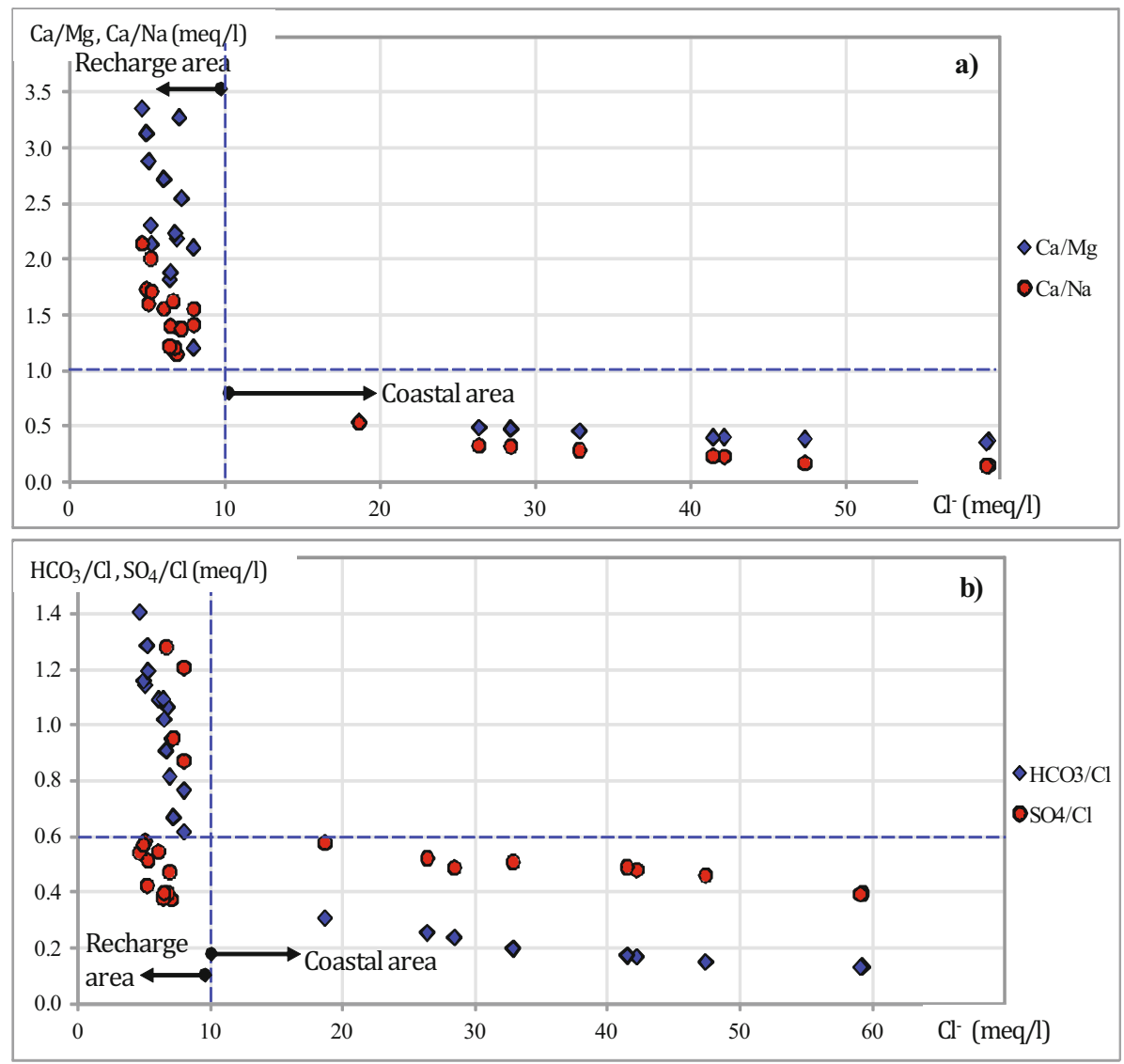

Fig. 7. Relationships of $\mathrm{Ca}^{2+} / \mathrm{Mg}^{2+}, \mathrm{Ca}^{2+} / \mathrm{Na}^{+}$(a), and $\mathrm{HCO}_{3}{ }^{-} / \mathrm{Cl}^{-}, \mathrm{SO}_{4}{ }^{2-} / \mathrm{Cl}^{-}$(b) versus $\mathrm{Cl}^{-}$(in meq/l).

moderately affected by seawater intrusion, and $<0.2$ for strongly affected by seawater intrusion (Mtoni et al. 2013, Kura et al. 2014).

Figure $7 \mathrm{~b}$ shows the relationship between $\mathrm{HCO}_{3}{ }^{-} / \mathrm{Cl}^{-}$and $\mathrm{SO}_{4}^{2-} / \mathrm{Cl}^{-}$ratios versus $\mathrm{Cl}^{-}$(in meq/1). While for upstream area the $\mathrm{HCO}_{3}{ }^{-} / \mathrm{Cl}^{-}$ratios have high values, to 0.4 , it could be explained by dilution of groundwater mineralisation after the rainfall infiltration and irrigation return, but this ionic ratios decrease and tend to " 0 " when the chloride concentration is in increase, suggesting that the groundwater in this coastal sector is affected by seawater intrusion (Kura et al. 2014), or to the important input of limestone or/and application of calcium carbonate on agricultural land (Mondal et al. 2010, Mtoni et al. 2013). The variation of $\mathrm{SO}^{2-} / \mathrm{Cl}^{-}$ratios was also employed to determine seawater intrusion. The origin of sulphate derived from action of 
leaching and anthropogenic activities. Hence, if the ratio is $<0.05$, then it is considered to be affected by seawater intrusion (Lagudu et al. 2013). In our study area, the $\mathrm{SO}_{4}{ }^{2-} / \mathrm{Cl}^{-}$ratios indicates a decrease (the tendency to the marine pole) for the coastal samples, while the low values in the recharge area $(<$ to 0.6$)$ show the influence of anthropogenic pollution most likely from degradation of organic materials from topsoil/water, or from oxidation/dissolution of $\mathrm{SO}_{4}{ }^{2-}$, reflecting sulphate-rich marine clay and silt deposits in reason of high values of sulphate (Rina et al. 2012).

\subsubsection{Cumulative Probability Curves}

Results of the interpretation of CPC for chosen hydrochemical ions (i.e., $\mathrm{Na}^{+}, \mathrm{Mg}^{2+}, \mathrm{Cl}^{-}$, and $\mathrm{SO}_{4}{ }^{2-}$ ) can be effectively used to differentiate between the samples whose chemistry is largely controlled by seawater mixing and the samples not affected by this latter. The intersection points in the cumulative probability plots can be considered as regional threshold values for differentiating the samples with the effect of seawater mixing in the study area (Fig. 8).

The approximate values obtained were $140 \mathrm{mg} / \mathrm{L}$ for $\mathrm{Na}^{+}, 40 \mathrm{mg} / \mathrm{L}$ for $\mathrm{Mg}^{2+}, 225 \mathrm{mg} / \mathrm{L}$ for $\mathrm{Cl}^{-}$, and $125 \mathrm{mg} / \mathrm{L}$ for $\mathrm{SO}_{4}{ }^{2-}$ (Fig. 8). Using the two parameters $\left(\mathrm{Cl}^{-}\right.$and $\left.\mathrm{Na}^{+}\right)$, the collected water samples are divided into two major groups as follows:
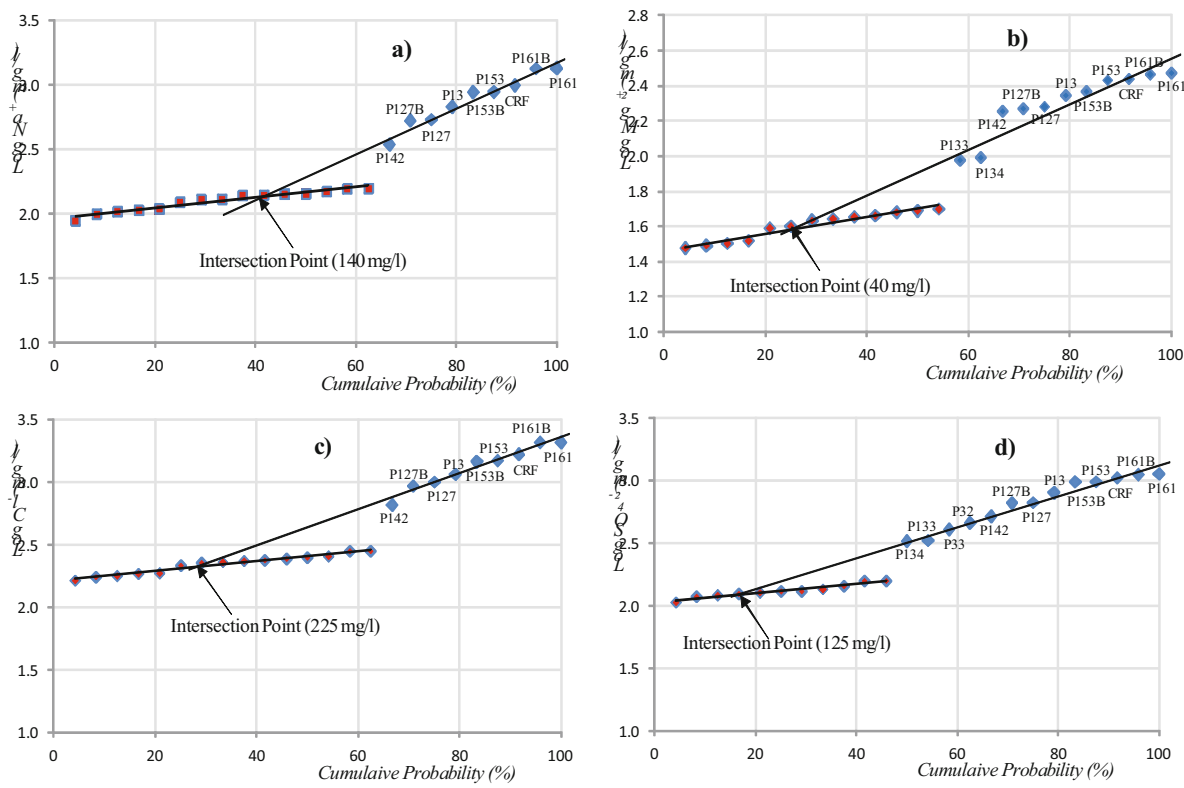

Fig. 8. Distribution of cumulative probability curves for the concentrations of $\mathrm{Na}^{+}$ (a), $\mathrm{Mg}^{2+}(\mathrm{b}), \mathrm{Cl}^{-}$(c), and $\mathrm{SO}_{4}{ }^{2-}$ (d) in groundwater. 
- Group $1(62.5 \%)$ : waters that are relatively poor in $\mathrm{Cl}^{-}$and $\mathrm{Na}^{+}$, concerning the samples localised in recharge area;

口 Group 2 (37.5\%): waters which are enriched in $\mathrm{Cl}^{-}$and $\mathrm{Na}^{+}$, indicating considerable influence of seawater mixing; concerning coastal samples (P142, P127B, P127, P13, P153B, P153, CRF, P161, and P161B).

This classification will be useful to discriminate the source of salinization, to estimate the level of seawater mixing, and ultimately to properly manage the groundwater resources in the study area. These graphs of cumulative probability of $\mathrm{Na}^{+}$and $\mathrm{Cl}^{-}$show broken lines in the point $\mathrm{P} 142$ (point number 16); it also shows probably that the mixing zone is located between wells P134 and P142.

Distribution of $\mathrm{CPC}$ of $\mathrm{SO}_{4}{ }^{2-}$ shows a break in the well 11, whilst the other ions indicate a break in the well 13, from the upstream to downstream of the plain. This is explained by a probable effect of domestic urban waste in rural agglomerations (sewerage system is not connected to the main system) in the upstream zone of the plain, and to the use of fertilizers (ammonium sulphate).

\subsubsection{Cluster Analysis}

Comparisons based on multiple parameters from different samples were made and the samples were grouped. The hydrochemical data, considered as observations, were classified by Cluster Analysis into 8 dimensional spaces $\left(\mathrm{Na}^{+}, \mathrm{Ca}^{2+}, \mathrm{Mg}^{2+}, \mathrm{K}^{+}, \mathrm{Cl}^{-}, \mathrm{HCO}_{3}^{-}, \mathrm{SO}_{4}{ }^{2-}, \mathrm{NO}_{3}{ }^{-}\right)$and the results are presented as a dendrogram of variables (Fig. 9) using furthest neighbor method. This method defines the Euclidean distance between two clusters as the maximum distance between any member of one cluster and a member of the other. The dendrogram of cluster variables of 24 monitoring wells shows the existence of a high correlation between $\mathrm{Na}^{+}$and $\mathrm{Cl}^{-}(r=0.99)$. It expresses that the mineralization is mainly influenced by those two ions. Groundwater in this

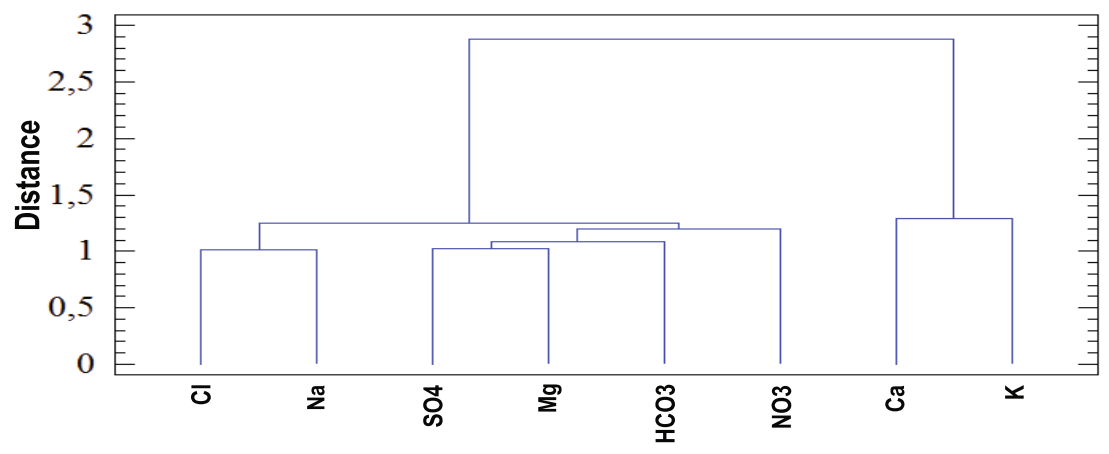

Fig. 9. Dendrogram of cluster analysis between variables. 


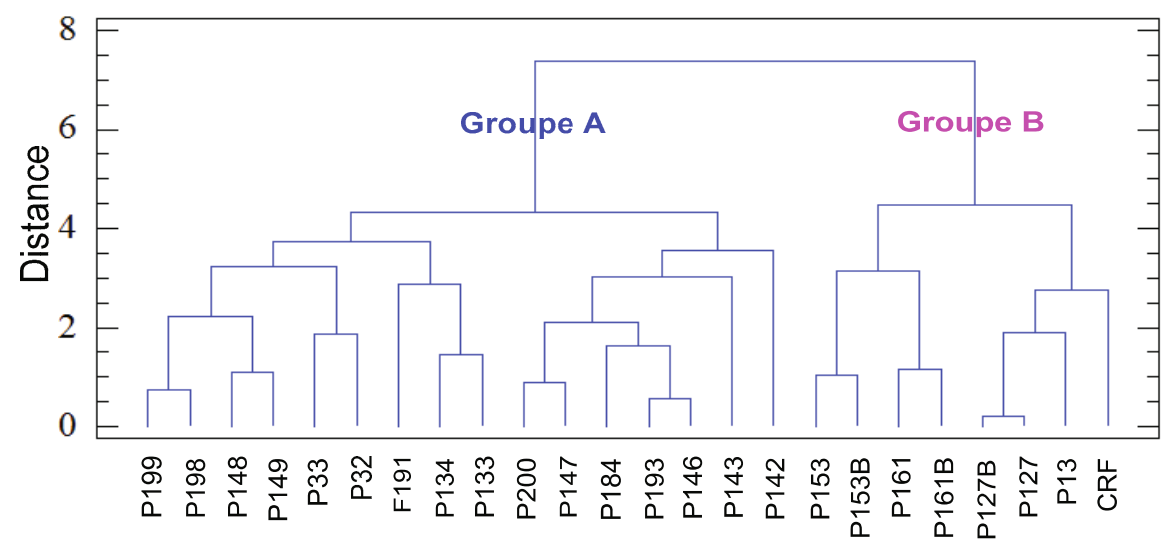

Fig. 10. Dendrogram of observations (24 samples).

area is also dominated by $\mathrm{SO}_{4}{ }^{2-}$ and $\mathrm{Mg}^{2+}$ (a high correlation between these two parameters, $r=0.98$ ), with a low correlation between $\mathrm{HCO}_{3}{ }^{-}$and $\mathrm{NO}_{3}{ }^{-}$ $(r=0.42)$ and very low correlation between $\mathrm{Ca}^{2+}$ and $\mathrm{K}^{+}(r=0.19)$.

The analysis of cluster observations shows two cluster groups, A and B (Fig. 10). There are sixteen samples identified within group A: samples of relatively freshwater with EC values ranging from 1400 to $1850 \mu \mathrm{S} / \mathrm{cm}$ and water types $\mathrm{HCO}_{3}-\mathrm{Cl}-\mathrm{Ca}-\mathrm{Na}, \mathrm{SO}_{4}-\mathrm{Cl}-\mathrm{Ca}-\mathrm{Mg}$ and $\mathrm{Cl}-\mathrm{SO}_{4}-\mathrm{Ca}-\mathrm{Na}$, and one sample of brackish water (P142) with EC of $2028 \mu \mathrm{S} / \mathrm{cm}$ and $\mathrm{Cl}-$ $\mathrm{SO}_{4}-\mathrm{Na}-\mathrm{Mg}$ water type, is situated in the transition zone. The water types of groups A can be interpreted as the first step of water-rock interactions occurring in dilute solutions, explained by the abundance of $\mathrm{Mix}-\mathrm{HCO}_{3}$ and Mix-Ca in the aquifer. It characterizes the water types in the recharge area.

The group B concerns the eight wells located near the coastal area at a distance less than $2 \mathrm{~km}$ (P127B, P127, P13, P153, P153B, CRF, P161, and $\mathrm{P} 161 \mathrm{~B})$. The EC of the water of these wells varies between 2600 and $4600 \mu \mathrm{S} / \mathrm{cm}$. Average concentrations of the chemical parameters in the group $\mathrm{B}$ samples (except $\mathrm{K}^{+}$and $\mathrm{Ca}^{2+}$ ) appear to be the highest among the group A. It is probably caused by a seawater intrusion in this part of plain.

\subsubsection{Groundwater quality zone}

All the above techniques were taken into consideration for establishing the final map of the affected area by salinity (Fig. 11).

It clearly delineates the different sectors of groundwater quality in this aquifer: the sector mostly contaminated by seawater intrusion, the probably transition zone, and the recharge area moderately mineralized.

The recharge area with 15 wells is characterized by high permeability, with low thickness relative to the coastal area and moderately high slope of 


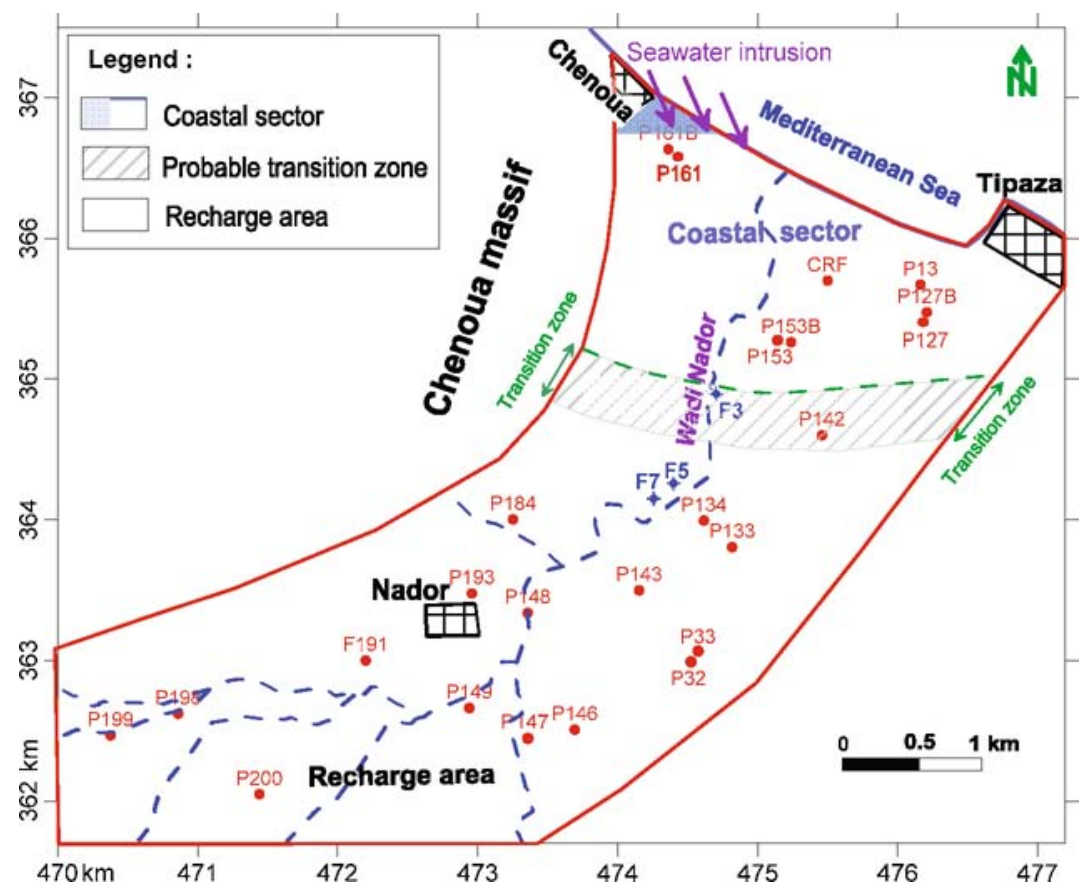

Fig. 11. Map of different sub-groups in coastal aquifer of Nador.

the substratum. It shows a groundwater quality moderately mineralized, while the transition zone (one well) is characterized by brackish water.

The statistical analysis applied shows also a group of 8 wells of high mineralization with probable penetration of seawater, which is due to the high permeability in this coastal sector and to the large thickness of aquifer; additionally, the dissolution of minerals present in the layers of the aquifer, and the groundwater natural discharge with an accumulation of some chemical elements (high residence time), make this coastal aquifer an area of high salinity.

\section{CONCLUSIONS}

The characterization of groundwater quality in Nador plain is the subject of this study, using major ion chemistry to establish the causes of groundwater salinization, and to understand the main processes that determine the chemistry of groundwater affected by salinization processes. The results of interpretation of physico-chemical parameters indicate that three principal mechanisms have been recognized: downstream sector (recharge area) with relatively freshwater (whose characteristics are related mainly to recharge by 
rainfall and irrigation), the transition zone (with moderate water quality), and the coastal sector in the first two kilometres, with higher salinity mainly related to seawater intrusion (mixing between freshwater and seawater).

These methods indicate that there are two distinct sets of samples, which are separated out from the cluster analysis and with cumulative probability curves. One set of samples characterizes the recharge area with 16 samples, and the second set of samples is influenced by seawater intrusion (in the coastal area), where the mixing rate of seawater intrusion is about $10 \%$.

We conclude that the salinization problem is related to natural recharge mechanisms and that seawater intrusion has a more local influence and must be considered as a process induced by overexploitation of water resources that exacerbates the deterioration of groundwater quality.

The applied methodology, using major ion chemistry, has been sufficient and effective to demonstrate the principal mechanisms that take part in the salinization of groundwater. The utility of the ionic ratios, cumulative probability curves and cluster analysis were demonstrated as powerful to identify and discriminate hydrogeochemical processes.

Acknowledgments. The authors gratefully acknowledge two anonymous reviewers for their critical evaluation and suggestions, which greatly helped to improve the manuscript.

References

Abarca, E., and T.P. Clement (2009), A novel approach for characterizing the mixing zone of a saltwater wedge, Geophys. Res. Lett. 36, 6, L06402, DOI: 10.1029/2008GL036995.

Anderson, M.S., V. Nyvang, R. Jakobsen, and D. Postma (2005), Geochemical processes and solute transport at the seawater/freshwater interface of a sandy aquifer, Geochim. Cosmochim. Acta 69, 16, 3979-3994, DOI: 10.1016/j.gca.2005.03.017.

APHA (1995), Standard Methods for the Examination of Water and Waste Water. 19th Edition, American Public Health Association, Washington.

Appelo, C.A.J, and D. Postma (2005), Geochemistry, Groundwater and Pollution, 2nd ed., A.A. Balkema Publ., Leiden.

Arslan, H. (2013), Application of multivariate statistical techniques in the assessment of groundwater quality in seawater intrusion area in Bafra Plain, Turkey, Environ. Monit. Assess. 185, 3, 2439-2452, DOI: 10.1007/s10661-0122722-x. 
Belkhiri, L., A. Boudoukha, and L. Mouni (2011), A multivariate statistical analysis of groundwater chemistry data, Int. J. Environ. Res. 5, 2, 537-544.

Bouderabala, A. (2015), Groundwater salinization in semi-arid zones: an example from Nador plain (Tipaza, Algeria), Environ. Earth Sci. 73, 9, 5479-5496, DOI: $10.1007 / \mathrm{s} 12665-014-3801-9$.

Bouderbala, A., and B. Remini (2014), Geophysical approach for assessment of seawater intrusion in the coastal aquifer of Wadi Nador (Tipaza, Algeria), Acta Geophys. 62, 6, 1352-1372, DOI: 10.2478/s11600-014-0220-y.

Bouderbala, A., B. Remini, and A. Pulido-Bosch (2014), Hydrogeological characterization of the Nador Plio-Quaternary aquifer, Tipaza (Algeria), Bol. Geol. Min. 125, 1, 77-89 (in Spanish).

Cardona, A., J.J. Carrillo-Rivera, R. Huizar-Álvarez, and E. Graniel-Castro (2004), Salinization in coastal aquifers of arid zones: an example from Santo Domingo, Baja California Sur, Mexico, Environ. Geol. 45, 3, 350-366, DOI: $10.1007 / \mathrm{s} 00254-003-0874-2$.

Charfi, S., K. Zouari, S. Feki, and E. Mami (2013), Study of variation in groundwater quality in a coastal aquifer in north-eastern Tunisia using multivariate factor analysis, Quat. Int. 302, 199-209, DOI: 10.1016/j.quaint.2012. 11.002 .

Chekirbane, A., M. Tsujimura, A. Kawachi, H. Isoda, J. Tarhouni, and A. Benalaya (2013), Hydrogeochemistry and groundwater salinization in an ephemeral coastal flood plain: Cap Bon, Tunisia, Hydrol. Sci. J. 58, 5, 1097-1110, DOI: $10.1080 / 02626667.2013 .800202$.

Custodio, E. (1987), Hydrogeochemistry and tracers. In: E. Custodio and G.A. Bruggeman (eds.), Groundwater Problems in Coastal Areas, Studies and Reports in Hydrology, Vol. 45, UNESCO, Paris, 213-269.

Custodio, E. (2002), Aquifer overexploitation: what does it mean? Hydrogeol. J. 10, 2, 254-277, DOI: 10.1007/s10040-002-0188-6.

Daniele, L., A. Vallejos, F. Sola, M. Corbella, and A. Pulido-Bosch (2011), Hydrogeochemical processes in the vicinity of a desalination plant (Cabo de Gata, SE Spain), Desalination 277, 1-3, 338-347, DOI: 10.1016/j.desal.2011.04. 052.

Djabri, L., S. Bouhsina, A. Hani, A. Pulido-Bosch, J. Mudry, and M.C. Djouamaa (2014), Impacts of drought on water quality: the case of aquifers in eastern Algeria. In: Proc. 6th IAHS-EGU Int. Symp. on Integrated Water Resources Management; June 2014, Bologna; Italy, Vol. 364, 357-362, DOI: 10.5194/piahs-364-357-2014.

El Moujabber, M., B. Bou Samra, T. Darwish, and T. Atallah (2006), Comparison of different indicators for groundwater contamination by seawater intrusion on the Lebanese coast, Water Resour. Manag. 20, 2, 161-180, DOI: 10.1007/ s11269-006-7376-4. 
Fidelibus, M.D. (2003), Environmental tracing in coastal aquifers: old problems and new solutions. In: Coastal Aquifers Intrusion Technology: Mediterranean Countries, Vol. 8, IGME Publ., Madrid, 79-111.

Giménez-Forcada, E., A. Bencini, and G. Pranzini (2010), Hydrogeochemical considerations about the origin of groundwater salinization in some coastal plains of Elba Island (Tuscany, Italy), Environ. Geochem. Health 32, 3, 243-257, DOI: 10.1007/s10653-009-9281-2.

Gupta, A.K., S.K. Gupta, and R.S. Patil (2005), Statistical analyses of coastal water quality for a port and harbour region in India, Environ. Monit. Assess. 102, 1-3, 179-200, DOI: 10.1007/s10661-005-6021-7.

Gurunadha Rao, V.V.S., G. Tamma Rao, L. Surinaidu, J. Mahesh, S.T. Mallikharjuna Rao, and B. Mangaraja Rao (2013), Assessment of geochemical processes occurring in groundwaters in the coastal alluvial aquifer, Environ. Monit. Assess. 185, 10, 8259-8272, DOI: 10.1007/s10661013-3171-X.

Khairy, H., and M.R. Janardhana (2013), Hydrogeochemical features of groundwater of semi-confined coastal aquifer in Amol-Ghaemshahr plain, Mazandaran Province, Northern Iran, Environ. Monit. Assess. 185, 11, 9237-9264, DOI: $10.1007 / \mathrm{s} 10661-013-3248-6$.

Kim, K.Y., Y.S. Park, G.P. Kim, and K.H. Park (2009), Dynamic freshwater-saline water interaction in the coastal zone of Jeju Island, South Korea, Hydrogeol. J. 17, 3, 617-629, DOI: 10.1007/s10040-008-0372-4.

Kolsi, S.H., S. Bouri, W. Hachicha, and H.B. Dhia (2013), Implementation and evaluation of multivariate analysis for groundwater hydrochemistry assessment in arid environments: a case study of Hajeb Elyoun-Jelma, Central Tunisia, Environ. Earth Sci. 70, 5, 2215-2224, DOI: 10.1007/s12665-0132377-0.

Kouzana, L., A.B. Mammou, and M.S. Felfoul (2009), Seawater intrusion and associated processes: Case of the Korba aquifer (Cap-Bon, Tunisia), C. R. Geosci. 341, 1, 21-35, DOI: 10.1016/j.crte.2008.09.008.

Kura, N.U., M.F. Ramli, S. Ibrahim, W.N.A. Sulaiman, and A.Z. Aris (2014), An integrated assessment of seawater intrusion in a small tropical island using geophysical, geochemical, and geostatistical techniques, Environ. Sci. Pollut. Res. 21, 11, 7047-7064, DOI: 10.1007/s11356-014-2598-0.

Lagudu, S., V.V.S.G. Rao, P.R. Prasad, and V.S. Sarma (2013), Use of geophysical and hydrochemical tools to investigate seawater intrusion in coastal alluvial aquifer, Andhra Pradesh, India. In: C. Wetzelhuetter (ed.), Groundwater in Coastal Zones of Asia-Pacific, Coastal Research Library, Vol. 7, Springer, Dordrecht, 49-65, DOI: 10.1007/978-94-007-5648-9_4.

Lakshmanan, E., R. Kannan, and M. Senthil Kumar (2003), Major ion chemistry and identification of hydrogeochemical processes of ground water in part of Kancheepuram district, Tamil Nadu, India, Environ. Geosci. 10, 4, 157166, DOI: $10.1306 /$ eg100403011. 
Lee, J.Y., and S.H. Song (2007), Evaluation of groundwater quality in coastal areas: implications for sustainable agriculture, Environ. Geol. 52, 7, 1231-1242, DOI: $10.1007 / \mathrm{s} 00254-006-0560-2$.

Li, G., X. Wang, Z. Meng, and H. Zhao (2014), Seawater inrush assessment based on hydrochemical analysis enhanced by hierarchy clustering in an undersea goldmine pit, China, Environ. Earth Sci. 71, 12, 4977-4987, DOI: 10.1007/ s12665-013-2888-8.

Liu, C.W., K.H. Lin, and Y.M. Kuo (2003), Application of factor analysis in the assessment of groundwater quality in a blackfoot disease area in Taiwan, Sci. Total Environ. 313, 1-3, 77-89, DOI: 10.1016/S0048-9697(02)00683-6.

Matiatos, I., A. Alexopoulos, and A. Godelitsas (2014), Multivariate statistical analysis of the hydrogeochemical and isotopic composition of the groundwater resources in northeastern Peloponnesus (Greece), Sci. Total Environ. 476-477, 577-590, DOI: 10.1016/j.scitotenv.2014.01.042.

Melloul, A., and M. Collin (2006), Hydrogeological changes in coastal aquifers due to sea level rise, Ocean Coast Manage. 49, 5-6, 281-297, DOI: 10.1016/ j.ocecoaman.2006.03.009.

Mondal, N.C., and V.P. Singh (2011), Hydrochemical analysis of salinization for a tannery belt in Southern India, J. Hydrol. 405, 3-4, 235-247, DOI: 10.1016/ j.jhydrol.2011.05.058.

Mondal, N.C., V.S. Singh, V.K. Saxena, and R.K. Prasad (2008), Improvement of groundwater quality due to fresh water ingress in Potharlanka Island, Krishna delta, India, Environ. Geol. 55, 3, 595-603, DOI: 10.1007/s00254007-1010-5.

Mondal, N.C., V.P. Singh, V.S. Singh, and V.K. Saxena (2010), Determining the interaction between groundwater and saline water through groundwater major ions chemistry, J. Hydrol. 388, 1-2, 100-111, DOI: 10.1016/j.jhydrol.2010. 04.032.

Mondal, N.C., V.P. Singh, S. Singh, and V.S. Singh (2011), Hydrochemical characteristic of coastal aquifer from Tuticorin, Tamil Nadu, India, Environ. Monit. Assess. 175, 1-4, 531-550, DOI: 10.1007/s10661-010-1549-6.

Mondal, N.C., V.P. Singh, and S. Ahmed (2013), Delineating shallow saline groundwater zones from Southern India using geophysical indicators, Environ. Monit. Assess. 185, 6, 4869-4886, DOI: 10.1007/s10661-012-2909-1.

Moral Callejón, S., A. Pulido-Bosch, and P. Valenzuela (1984), Aplicación de los análisis "cluster" al estudio de características físico-químicas de aguas subterráneas, Estud. Geol. 40, 3-4, 193-200, DOI: 10.3989/egeol.84403-4660 (in Spanish).

Mtoni, Y., I.C. Mjemah, C. Bakundukize, M. Van Camp, K. Martens, and K. Walraevens (2013), Saltwater intrusion and nitrate pollution in the coastal aquifer of Dar es Salaam, Tanzania, Environ. Earth Sci. 70, 3, 10911111, DOI: $10.1007 / \mathrm{s} 12665-012-2197-7$. 
Park, S.C., S.T. Yun, G.T. Chae, I.S. Yoo, K.S. Shin, C.H. Heo, and S.K. Lee (2005), Regional hydrochemical study on salinization of coastal aquifers, western coastal area of South Korea, J. Hydrol. 313, 3-4, 182-194, DOI: 10.1016/j.jhydrol.2005.03.001.

Pulido-Leboeuf, P. (2004), Seawater intrusion and associated processes in a small coastal complex aquifer (Castell de Ferro, Spain), Appl. Geochem. 19, 10, 1517-1527, DOI: 10.1016/j.apgeochem.2004.02.004.

Pulido-Leboeuf, P., A. Pulido-Bosch, M.L. Calvache, A. Vallejos, and J.M. Andreu (2003), Strontium, $\mathrm{SO}_{4}{ }^{2-} / \mathrm{Cl}^{-}$and $\mathrm{Mg}^{2+} / \mathrm{Ca}^{2+}$ ratios as tracers for the evolution of seawater into coastal aquifers: the example of Castell de Ferro aquifer (SE Spain), C. R. Geosci. 335, 14, 1039-1048, DOI: 10.1016/j.crte.2003. 08.004 .

Re, V., E. Sacchi, J. Mas-Pla, A. Menció, and N. El Amrani (2014), Identifying the effects of human pressure on groundwater quality to support water management strategies in coastal regions: A multi-tracer and statistical approach (Bou-Areg region, Morocco), Sci. Total Environ. 500-501, 211-223, DOI: $10.1016 /$ j.scitotenv.2014.08.115.

Rina, K., P.S. Datta, C.K. Singh, and S. Mukherjee (2012), Characterization and evaluation of processes governing the groundwater quality in parts of the Sabarmati basin, Gujarat using hydrochemistry integrated with GIS, Hydrol. Process. 26, 10, 1538-1551, DOI: 10.1002/hyp.8284.

Sarwade, D.V., M.V. Nandakumar, M.P. Kesari, N.C. Mondal, V.S. Singh, and B. Singh (2007), Evaluation of sea water ingress into an Indian atoll, Environ. Geol. 52, 8, 1475-1483, DOI: 10.1007/s00254-006-0592-7.

Saxena, V.K., V.S. Singh, N.C. Mondal, and S.C. Jain (2003), Use of hydrochemical parameters for the identification of fresh groundwater resources, Potharlanka, Island, India, Environ. Geol. 44, 5, 516-521, DOI: 10.1007/ s00254-003-0807-0.

Saxena, V.K., N.C. Mondal, and V.S. Singh (2004), Identification of sea-water ingress using strontium and boron in Krishna Delta, India, Curr. Sci. 86, 4, 586-590.

Sherif, M., A. El Mahmoudi, H. Garamoon, A. Kacimov, S. Akram, A. Ebraheem, and A. Shetty (2006), Geoelectrical and hydrogeochemical studies for delineating seawater intrusion in the outlet of Wadi Ham, UAE, Environ. Geol. 49, 4, 536-551, DOI: 10.1007/s00254-005-0081-4.

Singh, K.P., A. Malik, V.K. Singh, D. Mohan, and S. Sinha (2005), Chemometric analysis of groundwater quality data of alluvial aquifer of Gangetic plain, North India, Anal. Chim. Acta 550, 1-2, 82-91, DOI: 10.1016/j.aca.2005. 06.056 .

WHO (2011), Guidelines for Drinking-Water Quality, 4th ed., World Health Organization, Geneva, 564 pp., http://www.who.int/water_sanitation_health/ publications/2011/dwq_guidelines/en. 
Yidana, S.M. (2010), Groundwater classification using multivariate statistical methods: Southern Ghana, J. Afr. Earth Sci. 57, 5, 455-469, DOI: 10.1016/ j.jafrearsci.2009.12.002.

Zhang, X., Q. Wang, Y. Liu, J. Wu, and M. Yu (2011), Application of multivariate statistical techniques in the assessment of water quality in the Southwest New Territories and Kowloon, Hong Kong, Environ. Monit. Assess. 173, 14, 17-27, DOI: 10.1007/s10661-010-1366-y.

Received 5 November 2014

Received in revised form 8 April 2015

Accepted 22 April 2015 